\title{
Research on the Engineering Properties of Phosphogypsum Based on the Laboratory Test
}

\author{
Jing-Yi ZHANG \\ Sichuan Institute of Building Research, Chengdu, 610081, China \\ E-mail: zhangjingyi2000@qq.com
}

Keywords: Phosphogypsum; Shear Strength; Consolidation; Creep

\begin{abstract}
Phosphogypsum (PG) is one of the major solid wastes disposed on land. The safety evaluation of PG stacks is highly dependent on the correct characterization of its properties. Laboratory tests were performed to determine the physical and mechanical properties of PG, including its gradation, hydraulic conductivity, and consolidation characteristics. The shear strength of sedimented PG was determined through consolidated-undrained triaxial tests. Results show that PG is a dilatant granular material with a high internal friction angle. The odometer consolidation tests revealed that the consolidation of PG can last a long time after the initial sedimentation and the magnitude of consolidation caused by creep was significantly higher than that caused by compression. The measured vertical hydraulic conductivity of PG ranged from $10^{-5} \mathrm{~cm} / \mathrm{s}$ to $2 \times 10^{-4}$ $\mathrm{cm} / \mathrm{s}$, which is similar to that of silt. The CU triaxial tests showed that PG exhibits a dilalant behavior under all confining pressures and its shear strength is higher than that of most soil and mine tailings, with an effective peak friction angle of approximately $46.5^{\circ}$.
\end{abstract}

\section{Introduction}

Phosphogypsum (PG) is the most significant fertilizer industry by-product from phosphoric acid production using phosphate rock. Approximately 4.5 tons to 5.5 tons of PG are generated for every ton of phosphoric acid produced (as $\mathrm{P}_{2} \mathrm{O}_{5}$ ). Although PG is used as a construction material ${ }^{[1]}$, cement additive $^{[2]}$, soil amendment ${ }^{[3]}$ and chemical raw material ${ }^{[4]}$, the existing and newly generated gypsum greatly exceeds consumption. In the near future, most PG still needs to be piled on ground.

PG is usually hydraulically transported and deposited in PG stacks ${ }^{[5]}$. Similar to most mine tailings, PG stacks are usually operated using the upstream method; that is, the newly constructed containment dikes are founded on previously hydraulically deposited PG. Despite of the advantages of lowering operational costs, stacks raised using the upstream method are inherently more risky than other types of stacking methods ${ }^{[6]}$. A lack of understanding of the mechanical behavior of the disposed material may lead to improper design and slope failure accidents ${ }^{[7,8]}$. Therefore, the physical and mechanical behavior of PG must be understood and incorporated into the seepage and stability analyses of PG disposal facilities.

\section{Index Properties of PG}

The PG samples were retrieved from a PG stack in central China. Tests were performed to determine their specific gravity, Atterberg limits, grain size distribution, and soil classification. The basic physical properties of the PG samples are summarized in Table 1. The Unified Soil Classification System classifies PG as dilatant granular material with a high internal friction angle.

Table 1 Index Properties of PG

\begin{tabular}{rcccccc}
\hline $\begin{array}{c}\text { Specific } \\
\text { gravity }\end{array}$ & $\begin{array}{c}\text { Liquid } \\
\text { limit (\%) }\end{array}$ & $\begin{array}{c}\text { Plasticity } \\
\text { index (\%) }\end{array}$ & $\begin{array}{c}\text { Clay size fraction } \\
(<2 \text { um; \%) }\end{array}$ & $\begin{array}{c}\text { Fines } \\
\text { fraction }(<74 \\
\text { um; \%) }\end{array}$ & $\mathrm{Cu}^{*}$ & $\begin{array}{c}\mathrm{pH} \text { in } \\
\text { process } \\
\text { water }\end{array}$ \\
\hline 2.34 & - & - & 9 & 91 & 3 & 1.8 \\
\hline
\end{tabular}

* Coefficient of uniformity $\mathrm{C}_{\mathrm{u}}=\mathrm{D}_{60} / \mathrm{D}_{10}$ 


\section{Consolidation Property}

Four odometer consolidation tests were performed on the remolded PG specimens, which were pre-consolidated from slurry at a pressure of $30 \mathrm{kPa}$ in a batch consolidometer. The incremental vertical pressures of $50,100,200,400,800$, and $1600 \mathrm{kPa}$ were applied. The specimens were allowed to settle for $24 \mathrm{~h}$ under each pressure. The measured consolidation curves are presented in Fig. 1.

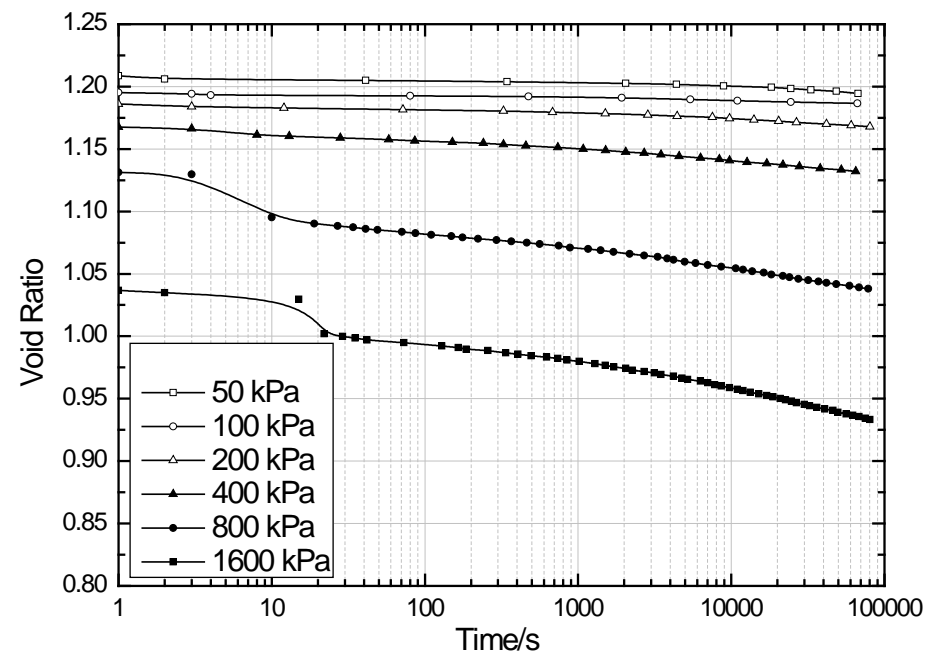

Figure 1 Consolidation curves of PG under four different vertical loads

\section{Hydraulic Conductivity}

The odometer consolidation apparatus was modified to measure the vertical hydraulic conductivity of each specimen at the end of the consolidation test. The hydraulic conductivity measurements were performed in accordance with the ASTM Standard D5856. A constant hydraulic pressure head of $10 \mathrm{~cm}$ was applied on the specimen and the flow rate through the specimen was measured. The vertical hydraulic conductivity of the specimen was then calculated. The measured hydraulic conductivities are plotted in Fig. 2 as a function of the void ratio. The figure shows that the vertical hydraulic conductivity of PG ranges from $10^{-5} \mathrm{~cm} / \mathrm{s}$ to $2 \times 10^{-4} \mathrm{~cm} / \mathrm{s}$, which is similar to that of silt ${ }^{[9]}$. The relationship between hydraulic conductivity and void ratio was derived and is presented in Eq. [1]. This relationship was used to determine the hydraulic conductivity of sedimented PG in the subsequent seepage analyses of the PG stacks.

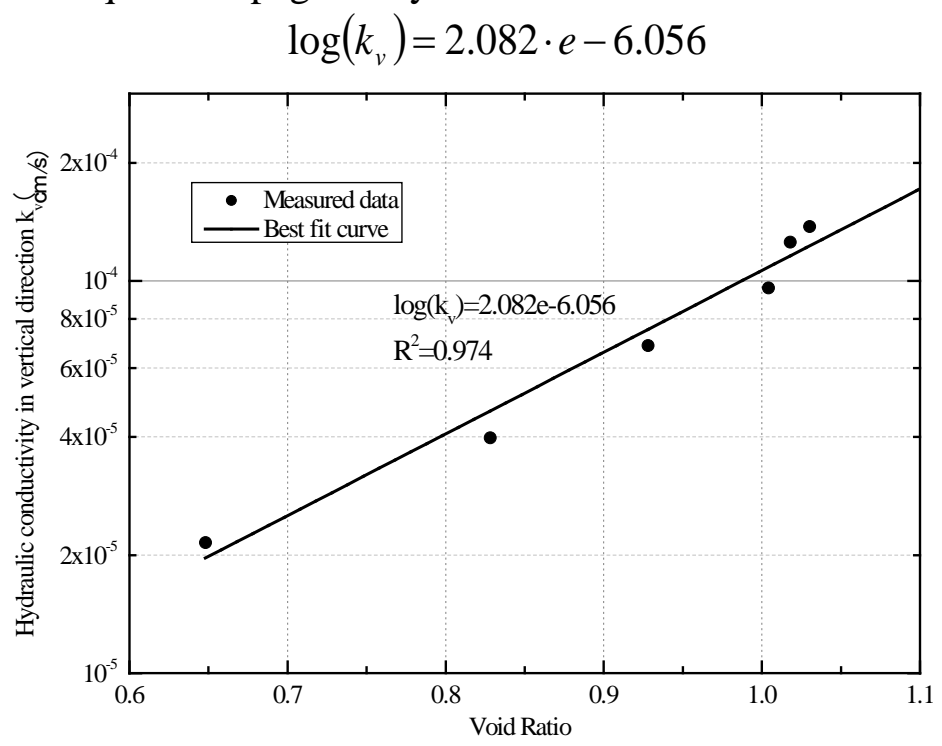

Figure 2 Vertical hydraulic conductivity versus void ratio relationship derived from laboratory tests 


\section{Shear Strength}

Five consolidated-undrained (CU) triaxial tests were performed on the remolded PG specimens. All the specimens were consolidated under a backpressure of $200 \mathrm{kPa}$ to achieve saturation prior to shear. The triaxial tests were then conducted at cell pressures of 200, 400, 600, and $1000 \mathrm{kPa}$ under undrained conditions. The samples were sheared at a rate of $0.02 \mathrm{~cm} / \mathrm{min}$ to allow for pore pressure equilibration during shear. The axial load, vertical strain, cell pressure, and pore pressure were continuously recorded throughout

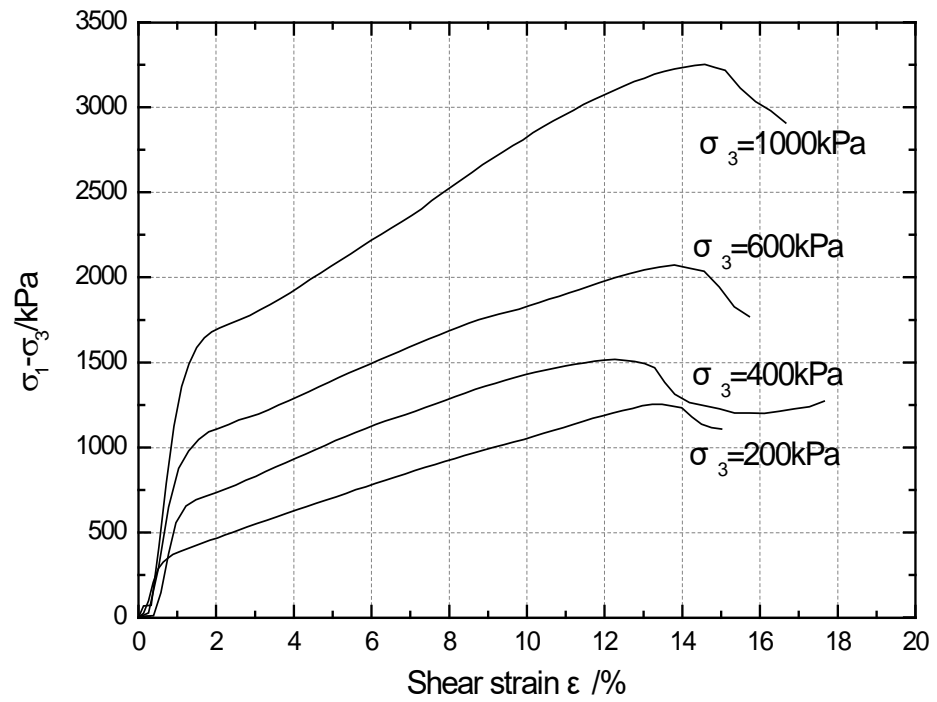

Figure 3 Shear stress versus shear strain of PG as derived from the CU triaxial tests

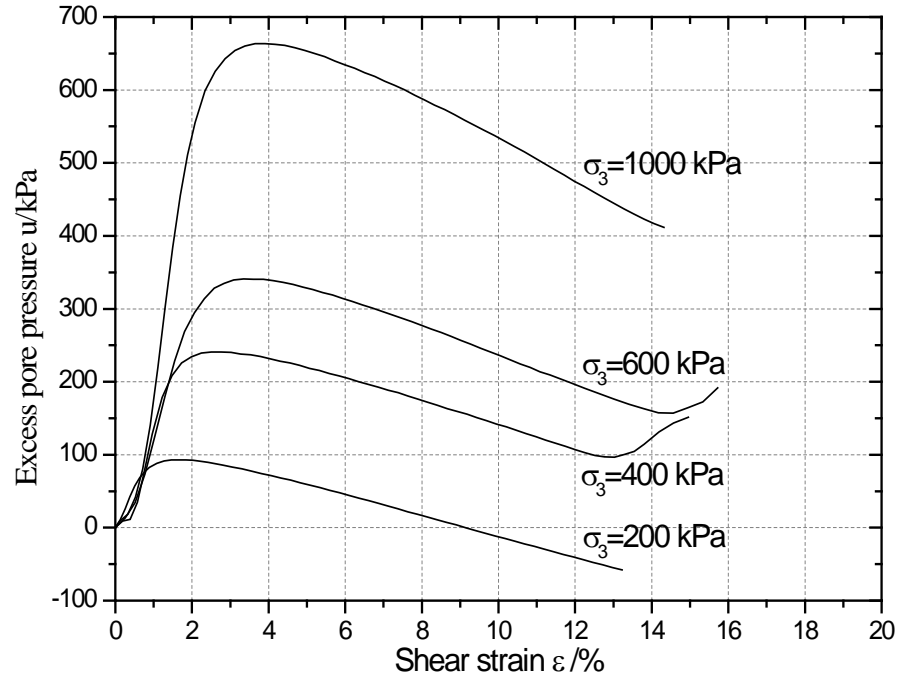

Figure 4 Excess pore pressure versus shear strain of PG as derived from the CU triaxial tests 


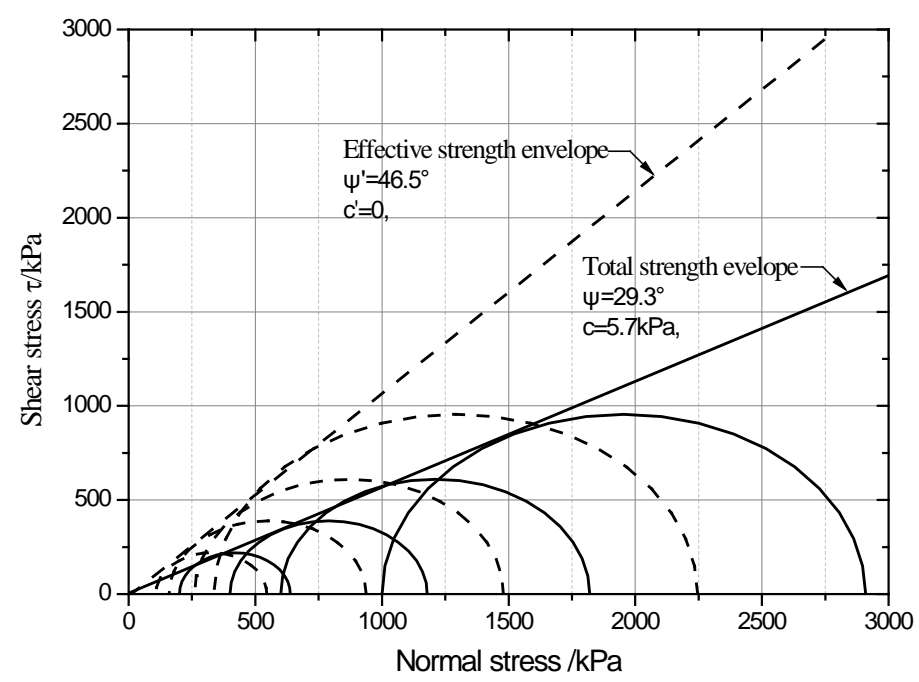

Figure 5 Total and effective shear strength of PG derived from the Mohr envelopes

the tests. Figs. 3 and 4 present the graphs of the shear stress and pore pressure versus axial strain for each test. The figures show that the samples generally display strain-hardening behavior (i.e., increasing shear resistance with increasing strain). The peak strengths occurred at axial strains of about $12 \%$ to $16 \%$. The excess pore pressures were positive at axial strains of approximately $2 \%$ to $4 \%$, but were became negative at higher axial strains, which indicates a dilatant behavior. The effective and total stress-strength envelopes (Mohr envelopes) were drawn on a $\square$ - $\square$ plot in Fig. 5 . The figure shows that the sedimented PG exhibited an effective peak friction angle of approximately $46.5^{\circ}$ with zero effective cohesion, which is much higher than that of most soil and mine tailings ${ }^{[10,11]}$. A total friction angle of $29.3^{\circ}$ and a total cohesion of $5.7 \mathrm{kPa}$ were measured.

\section{Conclusion}

A comprehensive laboratory study was conducted on the engineering properties of PG. The results showed that PG can be classified as nonplastic silt with evenly distributed particle sizes. The odometer consolidation tests revealed that the consolidation of PG can last a long time after the initial sedimentation and the magnitude of consolidation caused by creep was significantly higher than that caused by compression. The measured vertical hydraulic conductivity of PG ranged from $10^{-5} \mathrm{~cm} / \mathrm{s}$ to $2 \times 10^{-4} \mathrm{~cm} / \mathrm{s}$, which is similar to that of silt. The CU triaxial tests showed that PG exhibits a dilalant behavior under all confining pressures and its shear strength is higher than that of most soil and mine tailings, with an effective peak friction angle of approximately $46.5^{\circ}$.

\section{References}

[1] Kumar, S. (2003). Fly ash-lime-phosphogypsum hollow blocks for walls and partitions, Building and Environment, 38, 291-295.

[2] Kacimi, L., Simon-Masseron, A., Ghomari, A., \& Derriche, Z. (2006). Reduction of clinkerization temperature by using phosphogypsum, Journal of hazardous materials, 137, 129-137.

[3] Degirmenci, N., Okucu, A., \& Turabi, A. (2007). Application of phosphogypsum in soil stabilization, Building and Environment, 42, 3393-3398.

[4] Mei, F.D., Hou, J.J., Wang, Z., Chen, B.W., \& Gao, M. (2013). Physical and Chemical Properties Research for Phosophogysum-Based Silicon and Aluminum Composite Materials, Advanced Materials Research, 622, 1345-1349.

[5] Fuleihan, N.F. (2012). Phosphogypsum Disposal-The Pros \& Cons of Wet Versus Dry Stacking, Procedia Engineering, 46, 195-205. 
[6] Martin, T., \& McRoberts, E. (1999). Some considerations in the stability analysis of upstream tailings dams, Proc., Tailings \& Mine Waste, 287-302.

[7] Qiu, Y., \& Sego, D. (2001), Laboratory properties of mine tailings, Canadian Geotechnical Journal, 38, 183-190.

[8] Rutherford, P., Dudas, M., \& Samek, R. (1994). Environmental impacts of phosphogypsum, The science of the total environment, 149, 1-38.

[9] Santamarina, J.C., Klein, K., \& Fam, M. (2001), Soils and waves, John Wiley \& Sons, Chichester, UK.

[10] Dimitrova, R.S., \& Yanful, E.K. (2012). Factors affecting the shear strength of mine tailings/clay mixtures with varying clay content and clay mineralogy, Engineering Geology, 125, 11-25.

[11] Duncan, J.M., \& Wright, S.G. (2005). Soil strength and slope stability, John Wiley \& Sons. 